reception was given in the Laboratory of Physical Chemistry, at which Prof. and Mrs. Wiegner of Zurich were also present. In addition to exhibits of polarimetry, refractometry, ultra-violet and infrared spectroscopy, photochemistry, electron bombardment, molecular rays, and a number of exhibits in branches of physical chemistry less directly related to optical rotatory power, the adjoining Magnetic Laboratory was thrown open to inspection by permission of Sir Ernest Rutherford, and Dr. P. Kapitza was able to show the production of liquid and solid hydrogen, which has been suspended in Great Britain since the death of Sir James Dewar.

T. M. LowRy.

\section{Archæology and Bible History.}

DROF. JOHN GARSTANG'S Friday evening discourse on "The Historicity of the Books of Joshua and Judges " delivered at the Royal Institution on May 9 , apart from the intrinsic interest of any topic relating to the archæology of the Bible, was notable as affording some further examples of the way in which recent archæological investigation has served to confirm tradition. The discovery of evidence in Mesopotamia tending to substantiate the authenticity of the story of the Flood in the Bible and in Sumerian legend is a case in point; and Prof. Garstang himself referred to the confirmation of the Homeric account of Achæan activities in Asia Minor afforded by recent Hittite discovery.

Repeatedly when visiting sites under excavation in Palestine since the War, Prof. Garstang has been deeply impressed by the sense of material reality underlying the narrative in the Books of Joshua and Judges. It is now generally agreed, as the result of critical textual study, that these books in their present form were composed and amplified by various schools throughout a period of seven hundred years. For the purpose of his discourse, Prof. Garstang dealt only with the archæological problems raised by the older portion of the text; and it was with the specific object of studying these problems that his excavations at Jericho, Ai, and Hazor were undertaken in 1928. In addition he revisited every identified site mentioned in the oldest sources. No radical flaw was found in the topography and archæology of these documents.

The results of Prof. Garstang's investigations as summarised in his discourse are of profound interest and of singular significance in their bearing upon the historicity of these Bible narratives. All the identified sites mentioned in Joshua and Judges i. to v., such as Gezer, Megiddo, Bethshean, and Hazor, flourished in the Bronze Age, and for the most part were positions of strategic importance. The names of no less than twenty. four cities of the Canaanites in the age of Joshua are identicallwith those mentioned in the annals of Pharaohs of the xviiith Dynasty, especially from Tothmes III. to Akhenaten, that is from 1475 to 1375 в.c. Among the cities which the Israelites could not capture were Bethshean, Megiddo, Acco, Gezer, Jerusalem, and Gaza. These are found to be organised centres of Egyptian authority. It thus becomes clear that the background of the exploits of Joshua was that disclosed by the Egyptian records of the fifteenth century B.C.

Prof. Garstang's excavations at Jericho, Ai, and Hazor in 1928, and further investigations at Jericho early in the present year, fully bear out this interpretation. It has been found that each site shows traces of destruction near the middle of the late Bronze Age or about 1400 B.C. Ai and Hazor were abandoned as from that time, and Jericho was not rebuilt for centuries. At Bethel and Debir layers of destruction have been disclosed which are to be dated at the end of the fifteenth century. Bringing these results into relation with the tradition that the Exodus took place 480 years before the building of Solomon's temple, that is, about 1447 B.c., the date of Joshua's invasion of Canaan would fall about 1407 B.C. This tradition has been mistrusted ; but if the later additions to the Book of Judges are disregarded, the dis. crepancies disappear.

Thus, Prof. Garstang concludes, all available archæological and literary evidences point to the same date in the middle of the late Bronze Age, and the historical and topographical allusions in the Books of Joshua are found to be in accord with the material results of investigation. Further, Israel's position under the Judges falls into the frame afforded by Egyptian chronology and the record of Egyptian relations with Canaan. The records of both books were founded on fact.

\section{University and Educational Intelligence.}

BIRMINGHAM.-The University having been associaated with the Birmingham General Hospital as constituting the Birmingham centre of the Radium Commission, $1 \mathrm{gm}$. of radium has been lent by the Commission to the General Hospital and $0.5 \mathrm{gm}$. to the University. The radium lent to the University is to be used for the production of radium emanation (radon) and a small building for this purpose is being erected as part of the Physics Department under the control of the Poynting professor of physics, Prof. S. W. J. Smith. The radon produced is to be distributed to all hospitals which are at the present time recognised by the Faculty of Medicine as teaching institutions connected with the University. Certain other institutions in the area, on making application to the Faculty and furnishing evidence of suitability, will also be supplied.

Cambridge.-Dr. W. E. Dixon, of Downing College, has been reappointed reader in pharmacology.

Manchester.-A bronze plaque of the late Prof. W. H. Perkin, presented by former students and friends, will be unveiled in the Chemistry Theatre of the University on Saturday, May 24, at 11 A.M., and friends of the late Prof. Perkin are invited to be present.

The Council has accepted the offer of Mr. James Grier and Mr. Harry Brindle to institute two silver medals in pharmaceutics. The medals will be offered annually for competition to the students of the chemist and druggist course and of the pharmaceutical chemist and B.Sc. in pharmaceutics courses.

OXFORD.- The sixth annual report of the Lewis Evans Collection was presented to Convocation on May 6 by the curator, Dr. R. T, Gunther, of Magdalen College. It contains an account of the restoration work on the Old Ashmolean Building which has been carried out by the University Chest, and records the installation of the new armorial windows on the main staircase. A long list of accessions to the Collection is included, and the report goes on to point out that if the original "Officina Chemica" in the basement, at present used for the storage of books, could be made available, it would be possible to refit " the most historic laboratory in Britain with its own apparatus ", much of which was used there by Charles Daubeny a hundred years ago. The report ends with a record of the lectures and research work undertaken and the publications issued during the past year, together with a note as to the financial needs of the Collection.

On the motion of Dr. F. W. Pember, Warden of All Souls', Congregation has passed a decree authorising a grant of $£ 50$ towards the expenses of an expedition organised by a body of undergraduates who propose to make during the present year an ecological survey of Lapland and western Norway. 